\title{
Seal finger: A case report and review of the literature
}

\author{
Colin P White ${ }^{1}$, David D Jewer MD FRCSC ${ }^{2}$
}

CP White, DD Jewer. Seal finger: A case report and review of the literature. Can J Plast Surg 2009;17(4):133-135.

A recent case of seal finger which was misdiagnosed and hence mistreated at the patient's first presentation is described. The patient was eventually referred to a hand specialist and after the correct treatment with tetracycline, responded well without any long-term sequelae. Seal finger is an occupational injury that occurs to those who work directly or indirectly with seals. The disease entity has been described in both Scandinavian and Canadian literature. The causative microorganism was unknown until 1991, when Mycoplasma phocacerebrale was isolated from both the finger of a patient with seal finger and from the mouth of a seal that bit the patient. Although rare, the disease is not uncommon in marine workers, biologists and veterinarians. Prompt identification based on patient history and treatment with oral tetracycline is pendant to a favourable patient outcome.

Key Words: Case report; Mycoplasma phocacerebrale; Seal finger; Sealer's finger; Tetracycline

\section{Monoarthrite marine : Rapport de cas et revue de la littérature}

On décrit ici un cas récent de monoarthrite marine (ou seal finger) qui a été mal diagnostiqué et donc traité erronément lors de la première consultation du patient. Le patient a éventuellement été adressé vers un spécialiste de la main et après un traitement adéquat par tétracycline, il a bien répondu, sans séquelles à long terme. La monoarthrite marine est une maladie professionnelle qui affecte ceux qui travaillent directement ou indirectement avec des phoques. Cette entité clinique a été décrite dans la littérature scandinave et canadienne. On ignorait quel en était l'agent causal jusqu'en 1991, alors que Mycoplasma phocacerebrale a été isolé au niveau du doigt d'un patient atteint de la maladie et de la bouche d'un phoque qui l'avait mordu. Bien que peu fréquente, la maladie n'est pas rare chez les travailleurs, les biologistes et les vétérinaires de la mer. L'identification rapide fondée sur l'histoire du patient et un traitement par tétracycline orale donnent de bons résultats chez les patients.

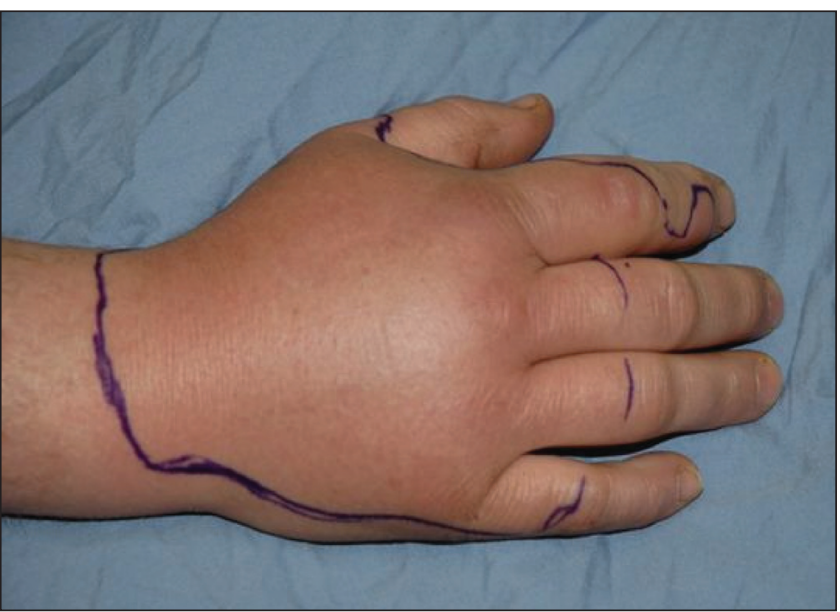

Figure 1) Dorsal surface of right hand showing outlined erythematous area extending to wrist

diagnosed with cellulitis and given cefazolin $2 \mathrm{~g}$ intravenously and probenecid $1 \mathrm{~g}$ orally.

The following day, he returned to the emergency department because his hand was increasingly more swollen and painful. His range of motion was now even more restricted. He was referred to a plastic surgeon. Upon appropriate history taking, the patient reported that the week before the onset of his symptoms, he had been hunting and skinning seals. On examination, his right hand and index finger was swollen and the finger was held in slight flexion, with erythema extending over the dorsum of his hand and wrist (Figure 1). A tentative on his index finger. There was no evidence of abscess. He was

${ }^{1}$ Division of Plastic Surgery, Discipline of Surgery, Faculty of Medicine, McMaster University, Hamilton, Ontario; ${ }^{2}$ Division of Plastic Surgery,

Discipline of Surgery, Faculty of Medicine, Memorial University, St John's, Newfoundland

Correspondence and reprints: Dr David D Jewer, Room 1842, Health Sciences Centre, Prince Philip Drive, St John's, Newfoundland A1B 3 V6.

Telephone 709-777-6437, fax 709-777-6295, e-mail djewer@mun.ca 


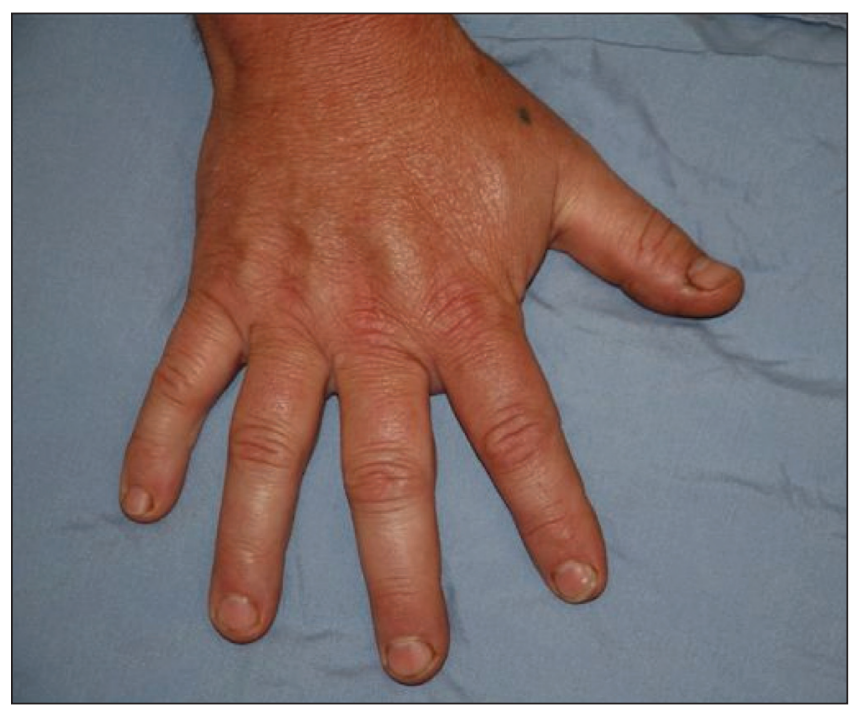

Figure 2) Dorsal surface of right hand showing resolution of erythema after treatment with tetracycline

diagnosis of seal finger was made and he was started on doxicycline for two doses and then switched to tetracycline $500 \mathrm{mg}$ four times a day for two weeks.

The patient was seen in follow-up two and a half days later. At this time, the swelling had settled, the erythema had decreased significantly and his range of motion had improved. He was told to complete his course of tetracycline and return for a recheck in two weeks. He did not keep his return appointment because his finger had improved. When seen for a separate problem three months later the finger was entirely normal (Figure 2)

\section{DISCUSSION}

Seal finger was first described by Bidenknap in 1907 (2). In the first half of the 20th century it was common in Norway and Newfoundland sealing fleets, where an estimated 10\% and $2.5 \%$ of the sealers were affected, respectively (3).

It most commonly occurred in people who either hunted or handled seal meat (4). Later in the 20th century many of those affected with seal finger were researchers and veterinarians (5). Traditionally, seal finger most commonly affected the middle and index finger because of the practice of placing these two digits through the eye slits of seal pelts to drag them along the ice.

Even from the earliest records, the disease entity was described as a painful, swollen, stiff, erythematous finger with possible axillary lymphadenopathy. Laboratory investigations show increased white blood cell count with neutrophilia $(4,6,7)$. X-rays are usually normal in the acute stage (7) but eventually may show joint destruction (5). The entrance of infection is through epithelial deficiency, or weakness of skin barrier $(4,8)$. The incubation period is reported to be from seven to 15 days (9).

Naming schemes for the disease include in English, seal finger or sealer's finger, and in Norwegian, 'spekkfinger' or 'speak finger', which means 'blubber finger'. In the Baltic seas, the term 'salrota', which means 'seal rot', is used. In the Gulf of Finland, other synonyms include 'salen I fingret', which means 'the seal in the finger', or from other translations 'seal blood in the finger', 'blubber in the finger' and 'blubber poisoning' (8).
Seal hunters and seal meat handlers are most likely to get the infection on the index or middle finger of the nondominant hand because this hand tends to get accidentally cut by the knife being used in the dominant hand $(9,10)$. Those actually bitten by a seal tend to have the thumb of the dominant hand affected $(5,11)$. These patients tend to be researchers and wildlife workers.

The differential diagnosis includes erysipeloid, atypical Mycobacterium (12) and Vibrio vulnificus infection (13). In erysipeloid, the erythema is much more intense and the causative organism Erysipelothrix rhusiopathiae can be cultured quite easily (5). Infection with atypical Mycobacteria also causes less pain than seal finger but is known to be very difficult to culture with normal methods (4).

Numerous case reports tell of adverse outcomes from the infection after incorrect treatment. These usually include the immediate consequences of pain, discomfort, decreased function and, in the long term, may include stiffness and permanent loss of finger joint range of motion (5). Other long-term consequences include ankylosis of interphalangeal joints, severe pain on movements or marked sensitiveness to cold. Surgical treatment for these problems included arthrodesis or amputation (4). It was not uncommon that a patient at sea on a fishing voyage would demand amputation of a finger to avoid losing valuable working time and wages (9).

Histological pathology reveals perivascular infiltration with lymphoctes and plasma cells in subcutaneous adipose tissue, and a few granulocytes without pus or necrosis. Fibrosis eventually takes place (4). Grossly joint pathology can be seen. Involved joints show severe inflammatory reaction with chronic granulation tissue and scarring with destruction of the articular cartilage (5).

Seals (Pinnipedia suborder) are classified as either eared, earless or walruses. The Canadian seal hunt includes harp seals (Pagophilus groenlandicus), the hooded seal (Cystophora cristata), the harbour seal (Phoca vitulina) and the grey seal (Halichoerus grypus), all which are hunted for their fur pelts (14). Harbour seals are earless and the most common associated with seal finger. Other types of sea mammals have been implicated in seal finger including elephant seals (Mirounga leonina) (5,13) and sea lions (7).

The disease may progresses from cellulitis to destruction of joints causing chronic damage $(9,11,12)$. Joint affection is characterized by synovitis, atropy of joint cartilage, bone reabsorption and eventually arthrosis (4).

The occupations of patients with seal finger can be divided into two main categories. Seal hunters and those who handle seal meat and pelts $(3,10,12,15,16)$ are the most commonly reported in the earlier literature. The other main group consists of those who work with live seals or in a marine environment. This group includes biologists $(3,13,14)$, psychologists (6), veterinarians (17), seal trainers $(1,18)$, researchers $(7)$ and aquarium personnel (5).

There are numerous case reports of patients being unsuccessfully treated with initial first line antibiotics (15). The consequences of incorrect choice antibiotics is usually an extended course of treatment (6), loss of recovery time and numerous consultations (7), unnecessary invasive procedures (17) and permanent damage to the joint $(11,12)$. One of the main reasons for incorrect treatment is possibly "lack of awareness by primary physicians of seal finger as a clinical entity" (5). 
Initial attempts to culture the causative organism using a variety of culture techniques were unsuccessful $(5,9)$. Russian researchers believed it was caused by Diplococcus. Because of the difficulty encountered while trying to identify a causative microbe, it was postulated the infection was of viral origin (8).

The link between seals and Mycoplasma was not proven until 1991. Mycoplasma species were first isolated from the trachea, bronchus, lung and heart in diseased harbour seals (Phoca vitulina) during an epizootic outbreak of seal pneumonia along the New England sea board in 1979 and 1980. The Mycoplasma strain was classified as the new species Mycoplasma phocidae $(19,20)$.

Later, in 1988 and 1989 in the Baltic Sea and North Sea during another mass mortality of seals, two new species - M phocacerebrale and Mycoplasma phocarhinis - were identified (21).

The discovery of Mycoplasma species in epidemics of seal disease prompted researchers to explore the possibility of Mycoplasmas as a cause of seal finger. They isolated $M$ phocacerebrale from the finger of an aquarium trainer who was bitten by a seal and also from the biting seal $(1,18,22)$. The isolates from the seal's mouth and the patient's finger were the same. The isolates were also identical to the Baltic Sea Mycoplasma strain M phocacerebrale but not the same as the New England strain M phocidae $(18,23)$. This observation by Madoff et al (21) in 1991 was the first documented case of Mycoplasma as the causative agent of sealer's finger. Mycoplasma species are known to cause both arthritis and be passed from one species to another (24).

Past traditional treatments of sealer's finger included dressing the affected digit with camphor oil, wheat flour paste and alcohol, soap with washing soda, and hot water (3). Other things like vinegar, brine, hot ash lye, linseed, pitch oil, rye flour, fur resin, pork slices and bear gall were also used. Other treatments have included magic spells recited over the finger, and stroking the tip of the finger with a feather from the left wing of a grouse (8). Treatments used in Canada included heat, splinting and amputation (9). Other treatments such as heat soaks, drainage and injections of penicillin were also used (10). Prophylactic techniques included hand washing with brine, petroleum, simple sap and wearing gloves (8).

\section{REFERENCES}

1. Baker AS, Ruoff KL, Madoff S. Isolation of Mycoplasma species from a patient with seal finger. Clin Infect Dis. 1998;27:1168-70.

2. Bidenknap JH, Spackflegmonen. Norsh Magazin for Legevidenskaben 1907;68:515-23.

3. Rodahl, K. "Spekk-Finger" or Sealer's Finger. Arctic 1952,5:235-40.

4. Bergholt A, Christensen RB, Cordtz T. Seal finger - diagnosis, prevention and treatment. Arctic Med Res 1989;48:3-5.

5. Mass D, Newmeyer W, Kilgore E. Seal finger. J Hand Surg [Am]. 1981;6:610-2.

6. Markham RB, Polk BF. Seal finger. Rev Infect Dis 1979;1:567-9.

7. Sargent E. Tetracycline for seal finger. JAMA 1980;244:437.

8. Candolin Y. Seal finger (spekkfinger) and its occurrence in the gulfs of the Baltic Sea. Acta Chir Scandanavica 1953;177:1-51.

9. Olds J. Seal finger or speck finger: A clinical condition seen in personnel handling hair seals. CMAJ 1957;76:455-7.

10. Skinner JS. Seal finger: The report of an occupational disease rare in the United States. AMA Arch Derm 1957;75:559-61.

11. Eadie PA, Lee TC, Niazi Z, Lawlor D. Seal finger in a wildlife ranger. Ir Med J 1990;83:117-8.

12. Bykerk VP, Tannenbaum H. The seal finger: An unusual case of monoarticular sepsis. J Rheumatol 1986;13:647-8.

13. Lewin MR, Knott P, Lo M. Seal finger. Lancet 2004;364:448.

14. Beck B, Smith TG, Seal finger: An unsolved medical problem in Canada. CMAJ 1976;115:105-9.
Early reports noted the effectiveness of chlortetracycline (aureomycin) for the treatment of seal finger $(8,10)$. Treatment regiments of 16 to 18 doses of aureomycin $250 \mathrm{mg}$ every $6 \mathrm{~h}$ for 10 days were used (9). There are documented cases of the infection's resistance to antibiotics including dicloxacillin, penicillin (5) and cephalexin (7,15). Patients with seal finger respond to tetracycline $(5,7,15)$.

Current recommended treatment for seal finger is tetracycline $1.5 \mathrm{~g}$ immediately and $0.5 \mathrm{~g}$ orally four times a day for two to six weeks $(5,12)$ or $1 \mathrm{~g}$ twice daily intravenously $(11,18)$. It was thought that because Mycoplasmas lack a cell wall, the disease does not respond to beta-lactam antibiotics (13).

\section{CONCLUSION}

Seal finger is an infection of the fingers caused by Mycoplasma species introduced by direct contact with seals. Seal finger has been well documented and studied in literature from the first half of the 20th century, when seal finger was more common and when antibiotics and proper occupational health and safety practices were not as advanced as they are currently.

The link between seals and Mycoplasma was not proven until 1991. The discovery of Mycoplasma species in epidemics of seal disease prompted researchers to explore the possibility of Mycoplasmas as a cause of seal finger. M phocacerebrale was isolated from the finger of an aquarium trainer who was bitten by a seal and also from the biting seal $(1,18,22)$. The observation by Madoff et al in 1991 was the first documented case of sealer's finger (23).

Prompt diagnosis and treatment with tetracycline is critical to preventing long-term complications. The subject has been reported but is relatively rare in occurrence. Increased education aids in the identification and prevention of this infection. Seal finger remains a disease seen seasonally in coastal Canada and is easily treated with good results. The present case report shows typical prolonged disease course secondary to improper diagnosis and treatment as well as good response after following basic principles of accurate history taking and diagnosis.

15. Denoncourt PM Seal finger. Orthopedics 1991;14:709-10.

16. White CP, de Wet F. Sealer's Finger. Can J Rural Med 2006;11:117-8.

17. Neil DT. Seal Finger. Article \#335, Alaska Science Forum, August 24, 1979.

18. Stadtlander CT, Madoff S. Characterization of cytopathogenicity of aquarium seal mycoplasmas and seal finger mycoplasmas by light and scanning electron microscopy. Zentralbl Bakteriol 1994;280:458-67.

19. Ruhnke HL, Madoff S. Mycoplasma phocidae sp. nov., isolated from harbor seals (Phoca vitulina L.). Int J Syst Bacteriol 1992;42:211-4.

20. Madoff S, Schooley RT, Ruhnke HL, et al. Mycoplasmal pneumonia in phocid (harbour) seals. Rev Infect Dis Suppl 4 1982:241.

22. Hartley JW, Pticher D. Seal finger - tetracycline is first line. J Infect 2002;45:71-5.

23. Madoff S, Ruoff K, Baker AS. Isolation of a Mycoplasma species from a case of seal finger. Abstract of the Annual Meeting of the American Society for Microbiology. Dallas Texas, May 5-9, 1991.

21. Giebel JJ, Meier A, Binder J, et al. Mycoplasma phocarhinis sp. nov. and Mycoplasma phocacerebrale sp. nov., two new species from harbor seals (Phoca vitulina L.). Int J Syst Bacteriol 1991;41:39-44.

24. Pitcher DG, Nicholas RA. Mycoplasma host specificity: Fact or fiction? Vet J 2005;170:300-6. 